\title{
The Regulation of Short Sales: A Politicised Topic
}

\section{Elizabeth Howell ${ }^{*}$}

(Word count: 5,736)

\section{Introduction}

'Short selling has been characterised as in-human, un-American, and against God (Proverbs 24:17: "Do not rejoice when your enemy falls, and do not let your heart be glad when he stumbles")."1

Short selling is a topic that often generates more heat than light. ${ }^{2}$ Views have differed on the practice and its regulation since the 17th Century, and short sellers provide easy targets for criticism during a crisis as they are seen as betting against the team; they profit when the share price falls. ${ }^{3}$ This paper considers the International Organisation of Securities Commissions' ('IOSCO's) principles on short selling regulation, and applies these to the legislation in place in the US, the EU, and Hong Kong. The US has had national short selling regulation in place in one form or other since the 1930s, whereas the EU has only regulated the practice as a regional matter since 2012. Hong Kong is an autonomous territory, a 'New York for China'; linked politically and economically, yet separate and primarily outward looking. ${ }^{4}$ Hong Kong's approach to short selling regulation has gone through a number of iterations over the years, including prohibiting the practice until the mid-1990s and then imposing a more stringent regime following the Asian Financial Crisis in the late 1990s.

The paper argues that short selling is beneficial for markets, and that the justifications for (particularly) permanent restrictions do not stand up to rigorous scrutiny. Moreover, national, or regional rules are unlikely to be effective in highly integrated markets. The paper suggests that politics is often the key factor shaping its regulation, and that regulators tend to respond to such drivers, producing a lack of international convergence. This generates risks, including of regulatory arbitrage. If there are constraints in place (particularly short selling bans), traders may simply move to another unregulated market, or invent a synthetic equivalent to replicate the banned activity. ${ }^{5}$ Although this could be perceived as a welcome outcome given short selling's benefits, arbitrage activity is not necessarily straightforward or cost-free. Moreover, new problems can materialise due to the uncertainties created through multiple regimes. Accordingly, if short selling is to be regulated, global harmonisation is necessary. At the same time, this is most likely impossible in practice. IOSCO's international standards in this area are

\footnotetext{
* Slaughter and May Lecturer in Corporate Law, Faculty of Law, Cambridge. The paper has benefitted from feedback following a presentation at the University of Hong Kong in September 2018. The usual disclaimers apply.

${ }^{1}$ Owen A. Lamont, 'Go Down Fighting: Short Sellers vs. Firms' (2012) 2 The Review of Asset Pricing Studies 1.

${ }^{2}$ Merritt B Fox, Lawrence R Glosten and Paul C. Tetlock, 'Short Selling and the News: A Preliminary Report on Empirical Study Fear, Fraud, and the Future of Financial Regulation Symposium' (2009) 54 New York Law School Law Review 645.

${ }^{3}$ Jonathan Macey, Mark Mitchell and Jeffry Netter, 'Restrictions on Short Sales: An Analysis of the Uptick Rule and Its Role in View of the October 1987 Stock Market Crash' (1988) 74 Cornell L Rev 799.

${ }^{4}$ David C. Donald, A Financial Centre for Two Empires (CUP 2014), chapter 1.

${ }^{5}$ See e.g. Benjamin M. Blau, Robert A. Van Ness and Richard S. Warr, 'Short Selling of ADRs and Foreign Market Short-Sale Constraints' (2012) 36 Journal of Banking \& Finance 886.
} 
framed at a high level of generality, and there is an absence of any firm enforcement mechanisms.

The paper is structure as follows: section 2 discusses the practice, regulatory concerns and available regulatory tools. Section 3 considers international principles and the three regimes under consideration. Section 4 highlights the key functional differences between the regulatory systems and the IOSCO principles. Section 5 briefly concludes.

\section{The Practice of Short Selling}

\subsection{What is Short Selling?}

Short selling concerns the sale of assets (often securities) not owned by the seller. The shares are generally borrowed from a third party with the intention of buying back equivalent assets at a later date to return to the lender. It is essentially a type of bet that the shares are overpriced; the short seller hopes to profit from the price fall between the sale and repurchase. There are two types of short sale; conventional or covered short selling where the shares are borrowed in advance, and naked short selling where no shares are borrowed in advance. Naked short selling is possible because there is a gap in time between the agreement to transfer shares to the buyer for a particular price and the requirement to actually do so. The gap in time enables the short seller to go into the market and buy the shares to deliver them to the buyer.

\subsection{How does Short Selling differ to Long Positions?}

Short selling can be distinguished from taking a long position or 'going long', which involves the more conventional method of buying shares, holding them, with a view to selling in the future for a profit. With a long position there is a fixed downside, the share price can only fall to zero, but the upside may be unlimited. In contrast, a short seller profits when the share price falls. Accordingly there is a fixed upside as the share price can only fall to zero, but the short seller's losses could be unlimited (often termed a 'short squeeze'). For example, the German carmaker Volkswagen briefly became the world's most valuable company in 2008 after disclosure of stakebuilding by Porsche sent the share price skyward and squeezed hedge funds into a scramble for stock. ${ }^{6}$ Moreover, although not culminating in a short squeeze, short sellers were hit in August 2018 following Tesla's Chief Executive, Elon Musk tweet that he was considering taking Tesla private. ${ }^{7}$

There are significant differences in the regulation of long and short positions. For instance, in the EU there are a small number of reporting obligations placed on directors, as well as broader notification requirements when shareholdings pass a certain threshold (as with Porsche). In contrast, short selling is subject to a significant level of regulation, and this difference in regulatory stance can be best explained by the fact that short selling is considered to be a morally dubious activity. Descriptions abound from short sellers as pecuniary vampires, and villains, and the fact that many short sellers are hedge funds compounds the perception that they are embracing unscrupulous strategies to profit on price falls.

\footnotetext{
${ }^{6}$ Armin Kammel, 'The Dilemma of Blind Spots in Capital Markets - How to Make Efficient Use of Regulatory Loopholes?’ (2009) 10 German LJ 605.

7 'Tesla Call Options Soar on Musk Tweet, Short-Sellers Hit’ Reuters (8 August 2018).
} 


\subsection{Regulatory Concerns}

Three main concerns are highlighted about short selling: market destabilisation; market abuse; and settlement risk. The market stability risk is most highlighted in falling markets where short selling can trigger a downward spiral in prices (a major concern in the crisis following the collapse of Lehman Brothers). Yet, economic scholarship almost overwhelmingly demonstrates short selling's beneficial impact on markets. ${ }^{8}$ Following the efficient capital markets hypothesis, which states that efficient markets are characterised by accurate pricing and high liquidity, short selling facilitates price corrections in overvalued stocks. ${ }^{9}$ Specifically, investors with negative information can reveal these beliefs through short selling. Short sellers can also provide an important counter-balance to the role of analysts, who may produce overly optimistic purchase recommendations that could otherwise fuel a speculative bubble. ${ }^{10}$ Short selling also increases market efficiency through enhancing liquidity and trading opportunities. It raises the number of potential sellers in the markets, and in the absence of constraints, short sellers will find it easier to trade as will their trading partners.

With respect to the crisis conditions, evidence since 2008 suggests that short selling was not the main reason behind the drastic price falls, and that other factors, such as poor company performance, the media, and long sellers played a more significant role with respect to the downward price pressure. ${ }^{11}$ Moreover, empirical studies examining the imposition of temporary short selling bans around the world showed that these slowed down price discovery and failed to support prices. ${ }^{12}$

Despite these findings, it is understandable that regulators prioritise financial stability during a crisis over other objectives such as market efficiency. There can be real concerns as to the risk of financial dominos following the failure of systemically important banks. When this is taken in conjunction with investors over-reacting to negative information, arguments can certainly be made justifying temporary short selling bans on particular credit institutions. ${ }^{13} \mathrm{Be}$ that as it may, particularly given that short selling bans may not achieve their aim, it can be hard to see what is achieved, other than of regulators being seen to be acting. ${ }^{14}$

\footnotetext{
${ }^{8}$ Theoretical literature includes the seminal paper by Edward M. Miller, 'Risk, Uncertainty, and Divergence of Opinion' (1977) 32 J Fin 1151. Empirical studies abound see e.g. Arturo Bris, William N. Goetzmann and Ning Zhu, 'Efficiency and the Bear: Short Sales and Markets around the World' (2007) 62 J Fin 1029.

${ }^{9}$ Eugene F. Fama, 'Efficient Capital Markets: A Review of Theory and Empirical Work' (1970) $25 \mathrm{~J}$ Fin 383; Pedro A. C. Saffi and Kari Sigurdsson, 'Price Efficiency and Short Selling' (2011) 24 Rev Fin Stud 821.

${ }^{10}$ See e.g. Michael S. Drake, Lynn Rees and Edward P. Swanson, 'Should Investors Follow the Prophets or the Bears? Evidence on the Use of Public Information by Analysts and Short Sellers' (2011) 86 Acc Rev 101.

${ }^{11}$ See e.g. Office of Economic Analysis, 'Analysis of Short Selling Activity During the First Weeks of September 2008' (2008); FSA, 'Short Selling Discussion Paper 09/1' (2009).

${ }^{12}$ See e.g. Matthew Clifton and Mark Snape, 'The Effect of Short-Selling Restrictions on Liquidity: Evidence from the London Stock Exchange' (2008); Alessandro Beber and Marco Pagano, 'ShortSelling Bans around the World: Evidence from the 2007-09 Crisis' (2013) 68 J Fin 343.

${ }^{13}$ See Markus K. Brunnermeier and Martin Oehmke, 'Predatory Short Selling' (2013) 18 Review of Finance 2153; John Armour and others, Principles of Financial Regulation (OUP 2016).

${ }^{14}$ Luca Enriques, 'Regulators' Response to the Current Crisis and the Upcoming Reregulation of Financial Markets: One Reluctant Regulator's View' (2009) 30 University of Pennsylvania Journal of International Law 1147.
} 
The second concern, of market abuse, most particularly of manipulating the market in a stock, is certainly a serious risk. Yet, developed jurisdictions have market abuse regulation in place, and if such provisions are unsatisfactory, this merits a re-consideration of these rules and their enforcement. It is not immediately clear that additional ex ante short selling constraints are the answer, particularly as this would limit valuable shorting activity. The final concern of settlement failure is especially highlighted with naked short selling where the shares are not borrowed in advance. Yet, strict settlement regimes and penalties for default can incentivise traders to settle their trades.

Taken together, the practice of short selling does not create insurmountable problems for markets; moreover the imposition of short sale restrictions may be ineffective and impede market efficiency.

\subsection{If Short Selling is Regulated - With Which Tools?}

If the decision is made to regulate, a number of techniques are available (which need not be mutually exclusive). Reporting requirements can be imposed whether privately to the regulator and/or publicly to the market. If there is public disclosure, this can also be of individual short positions, or anonymously via aggregating short positions. Strict settlement periods can be imposed (such as trade plus three days) plus consequences for fails to deliver. A more rigorous strategy can also involve what is termed a 'tick rule' such as only requiring short sales to take place when the share price is rising. This could be utilised in conjunction with a circuit breaker that halts short selling when share prices fall by a particular amount. There can also be the imposition of bans ranging from permanent bans on all or naked short sales, to temporary constraints, whether on all or only on sector-specific entities.

The wide range of regulatory responses to the practice can be evidenced with respect to the stance taken to regulation in the US, the EU and Hong Kong. As identified in section 1, given the international nature of financial markets, differing approaches are likely to be ineffective. Although this may not, at first glance, seem a bad outcome given short selling's benefits; it generates inefficiencies and the likelihood of regulatory arbitrage.

\section{Divergent Responses}

\subsection{IOSCO: International Regulation?}

At the international level, IOSCO is recognised as the global standard setter with respect to the securities sector. ${ }^{15}$ It gathers together the world's securities regulators and it has members in over 115 jurisdictions (including the US, Hong Kong, and the EU Member States); a 'United Nations' of securities organisations. ${ }^{16}$ Its worldwide membership brings varying legal and market structures to the table, and although it generally operates on a consensus culture, it

\footnotetext{
${ }^{15}$ IOSCO, 'About IOSCO’ (2018) <https://www.iosco.org/about/?subsection=about_iosco $>$ accessed 5 September 2018

${ }^{16}$ There are three categories of members. Ordinary members are securities regulators; associate members are usually supranational organisations; affiliate members are private self-regulatory organisations. The EU is represented by the European Commission and the European Securities and Markets Authority (as Associate Members), Pierre-Henri Conac, The European Union's Role in International Economic Fora. Paper 6: The IOSCO. Study for the European Parliament. (2015); Niamh Moloney, 'International Financial Governance, the EU, and Brexit: The 'Agencification' of EU Financial Governance and the Implications' (2016) 17 EBOR 451, 470-1.
} 
can be tricky to agree strong common standards. ${ }^{17}$ The outcome of this is that its standards tend to be not sufficiently detailed to form the basis of international or regional harmonisation.

With respect to short selling regulation, IOSCO set up a short selling Task Force following the financial crisis. Its Final Report identifies that short selling regulation varies considerably among members and its principles are geared towards ensuring a more consistent international regulatory approach. The Report also acknowledges the potentially beneficial effects of the practice and seeks to limit political pressure to ban the practice or to impose an uptick rule. ${ }^{18}$ IOSCO sets out four principles. It recommends that short selling be subject to appropriate controls to minimise risks, including to financial stability (with strict settlement of failed trades as a minimum; in effect a ban on naked short sales). Second, short selling should also be subject to a reporting regime providing timely information to the market or market authorities. Third, there should be effective compliance and enforcement regimes in place. Finally, its regulation should allow appropriate exceptions (such as for market making and arbitrage activities). ${ }^{19}$

As observed above, the light touch nature of these principles can be best understood as the product of compromise; in particular there were considerable disagreements between various jurisdictions as to the need for short selling regulation, and, if so, using which tools. ${ }^{20}$

\subsection{National and Regional Responses}

The IOSCO principles can be applied to the three systems under consideration. The table below articulates the main functional similarities and differences with the IOSCO principles to guide the discussion in sections 3.3-3.5 below. The approaches highlighted in bold are (in general terms) in line with IOSCO's principles.

\begin{tabular}{|l|c|c|c|}
\hline & Hong Kong & US & EU \\
\hline Permanent Ban & $\begin{array}{c}\text { Yes (if not on the } \\
\text { eligibility list) }\end{array}$ & No & No \\
\hline $\begin{array}{l}\text { Ban on Naked Short } \\
\text { Sales }\end{array}$ & Yes & Yes (de facto) & Yes (de facto) \\
\hline No Tick Rule & Tick Rule & $\begin{array}{c}\text { Tick Rule } \\
\text { (temporary basis) }\end{array}$ & No Tick Rule \\
\hline Disclosure Rules & Yes & Yes & Yes \\
\hline Enforcement & Yes & Yes & $\begin{array}{c}\text { Varies (country } \\
\text { dependent) }\end{array}$ \\
\hline
\end{tabular}

\footnotetext{
${ }^{17}$ Nicolas Véron, 'Financial Regulation: The G20's Missing Chinese Dream' Policy Contribution Issue No 19 (2016) <http://bruegel.org/wp-content/uploads/2016/10/PC-19-2016.pdf > accessed 13 September 2018; Eilis Ferran, 'Regulatory Parity in Post-Brexit UK-EU Financial Regulation' in Brexit and Financial Services: Law and Policy (Hart Publishing 2018) 24.

${ }^{18}$ Roberta S. Karmel, 'IOSCO's Response to the Financial Crisis' (2012) 37 J Corp L 849, 880.

${ }^{19}$ IOSCO, 'Regulation of Short Selling, Final Report' (June 2009) 5.

${ }^{20}$ Jennifer Payne, 'The Regulation of Short Selling and Its Reform in Europe' (2012) 13 EBOR 413, 429.

${ }^{21}$ These are general observations; this is not an empirical analysis. Note for all three jurisdictions, enforcement of short selling regulation is also possible under broader market abuse/market misconduct regulation.
} 


\begin{tabular}{|l|c|c|c|}
\hline Exceptions & Yes & $\begin{array}{c}\text { Yes (but not for tick } \\
\text { rule) }\end{array}$ & Yes \\
\hline
\end{tabular}

\subsection{US Regulatory Stance}

US short selling regulation stems from the 1930s: a wide range of provisions apply, and these can also extend to overseas transactions that are agreed in the US. ${ }^{22}$ The rules include constraints on all short sales before seasoned equity offerings (share offerings by traded companies). The combination of a 'locate rule' (broadly, that a broker-dealer has reasonable grounds to believe the share can be borrowed) plus tight settlement rules (trade ' $T$ ' +3 ) equate to a de facto ban on naked short sales. ${ }^{23}$ Although the US securities regulator, the Securities and Exchange Commission (the 'SEC'), removed a price restriction rule before the global crisis hit, it re-introduced a so-called alternative uptick rule in the aftermath. This provides that if the share price drops by $10 \%$ or more, a circuit breaker kicks in. An uptick restriction then applies for the remainder of the day and the following day (which can be retriggered). There are also some short sale reporting requirements but these do not constitute a major aspect of US regulation. Such provisions include 'flagging' orders as 'short'; and private self-regulatory organisations (such as FINRA) publish aggregated data (short sale volume on a daily basis; anonymised individual transactions on a one-month delayed basis). ${ }^{24}$ Some exemptions are in place for market-making activities, although not in relation to the tick rule. At the enforcement level, in general terms, the US has a long-standing wide commitment to active enforcement with respect to market misconduct. Moreover, historically, the intensity of public enforcement has been high in the US. ${ }^{25}$

The US short selling provisions are fairly onerous and this can be best explained by the fact the SEC is an agency 'at once independent and beholden' ${ }^{26}$ The President appoints its Commissioners and Chair, and the SEC has to go to Congress on an annual basis for its funding. Congress keeps a tight rein on SEC policy, including via the budgetary process. The SEC was also diminished in stature as a regulator during the crisis and it faced much political pressure, including in relation to imposing temporary short selling bans. This likely also influenced the SEC's stance to short selling regulation post-crisis, most evidently in relation to the re-imposition of a price restriction rule. ${ }^{27}$

\subsection{The EU}

${ }^{22}$ SEC, 'Amendments to Regulation SHO, Release No. 34-61595 (Final Rule)' (February 26, 2010) 157-8 (providing that the rules cover short sales effected using US jurisdictional means, regardless of the jurisdiction in which they are executed).

${ }^{23}$ SEC, Short Sales, Release No 34-50103 (Final Rule) (July 2004); SEC, Amendments to Regulation SHO, Release No 34-60388 (Final Rule) (July 2009).

${ }^{24}$ Elizabeth Howell, 'Short Selling Reporting Rules in the EU and the US: A Greenfield Area' (2015) 12 European Company Law Journal 79.

${ }^{25}$ See the seminal contribution by John Coffee, 'Law and the Market: The Impact on Enforcement' (Columbia Law and Economics Working Paper No 304, 7 March 2007). At the same time it should be reiterated that these are general and not empirical observations. There are limitations on available data and it can be tricky to make like-for-like comparisons between the jurisdictions.

${ }^{26}$ Erik R. Sirri, 'Regulatory Politics and Short Selling' (2010) 71 University of Pittsburgh Law Review $517,535$.

${ }^{27}$ See also Elizabeth Howell, 'Short Selling Restrictions in the EU and the US: A Comparative Analysis' (2016) 16 Journal of Corporate Law Studies 333. 
A number of unilateral and uncoordinated bans were introduced in different Member States during the financial crisis. Following this there continued to be a range of national approaches prior to the introduction of the EU's regional rules. The UK principally relied on disclosure provisions, while Germany introduced a permanent regime that included bans on some forms of short selling. ${ }^{28}$ At the EU level, the question of short selling regulation then became somewhat entwined with that of hedge fund regulation, particularly due to the short selling activity of hedge funds being perceived to have contributed to the severe price declines during the crisis. During the euro-zone sovereign debt crisis, speculators were also accused of worsening the fiscal woes of euro-zone countries through raising government borrowing costs. Somewhat charged political battles ensued during the Regulation's negotiations and the politicisation of the resulting regime is particularly evident in its regulation of sovereign (but not corporate) debt as well as the short selling of shares.

As with the US rules, the EU's Short Selling Regulation ('SSR') has extra territorial reach, its parameters are set by the instruments subject to it, not the domicile or establishment of the market participants. ${ }^{29}$ Its provisions include a prohibition on the naked short selling of all shares and sovereign debt, plus a ban on entering into uncovered sovereign credit default swaps (an equivalent mechanism to directly short selling the sovereign debt) ${ }^{30}$ Under related legislation there are strict settlement rules $(\mathrm{T}+2)$ imposed plus mandatory buy-ins for fails to deliver. ${ }^{31}$ Accompanying the restrictions are reporting requirements; two-tier private and public reporting is required of individual net short positions (private reporting commences at $0.2 \%$, public at $0.5 \%$ ), although only private reporting is required in relation to sovereign debt. $^{32}$

In exceptional circumstances a wide range of temporary intervention measures can be imposed by national regulators (including circuit breaker mechanisms), as well as exceptionally via the European Securities and Markets Authority ('ESMA'). ${ }^{33}$ ESMA has not yet used its direct emergency powers, even following the outcome of the 'Brexit' vote. That being said, despite the national authority/ESMA coordination in advance of the referendum, trading in RBS and Barclays' shares was briefly suspended on the Monday after the vote as the share prices fell so fast in the face of the political surprise. ${ }^{34}$

The SSR has exemptions in place from the prohibitions and reporting where the principal trading venue for the shares is located in a third country. There are also exemptions for market-making activities in relation to the prohibitions and the reporting requirements (shares and sovereign debt). ${ }^{35}$ At the enforcement end, penalties for direct infringements of the SSR

\footnotetext{
${ }^{28}$ Payne (n 20) 424-8.

${ }^{29}$ Regulation (EU) No 236/2012 on Short Selling and Certain Aspects of Credit Default Swaps [2012] OJ L86/1, art 1.

${ }^{30}$ Ibid, arts 12-14.

${ }^{31}$ Regulation (EU) No 909/2014 of 23 July 2014 on Improving Securities Settlement and on Central Securities Depositories OJ L257/1.

${ }^{32}$ Regulation 236/2012, arts 5-7.

${ }^{33}$ Ibid arts 18-23; art 28.

${ }^{34}$ Ibid 18-23, 28; see 'Market Infrastructure Coped Well with Brexit Fallout: EU Watchdog' Reuters (29 June 2016) <https://www.reuters.com/article/us-britain-eu-esma/market-infrastructure-coped-wellwith-brexit-fallout-eu-watchdog-idUSKCNOZFOUC $>$ accessed 13 September 2018. At the time of writing ESMA has issued 20 opinions on national regulators' temporary measures, these have generally been supportive apart from one negative opinion with respect to the proposed extension of a Greek ban in 2016, ESMA, Opinion on Greek Emergency Measures (ESMA/2016/28).

${ }^{35}$ Regulation 236/2012, arts 16-17.
} 
are not harmonised; these are Member State dependent. This is a weak point of the Regulation; sanctions can vary considerably between jurisdictions. For example in Belgium, fines are not to be under 250 euro per day and not to exceed 2.5 million euro. In France, the fines can be up to 100 million euro. ${ }^{36}$ At the same time, sanctions can be levied under the market abuse regime, and the post-crisis EU market abuse rules now adopt a more prescriptive approach to penalties. ${ }^{37}$

The Regulation's enactment further supports the argument that a crisis creates the opportunity to push through reforms that have little connection with the event itself. ${ }^{38}$ Indeed the scapegoating of short sellers can be more akin to shooting the messenger rather than listening to the message. ${ }^{39}$ That short selling is a politicised topic is also clear in the SSR's focus on regulating the short selling of sovereign debt.

\subsection{Hong Kong}

Hong Kong's short selling regime has been claimed by its regulators to be robust; unlike the US, and the EU, it did not impose additional temporary constraints or bans during the global crisis. ${ }^{40}$ On the other hand, its system has been criticised as being 'archaic' ${ }^{41}$ This section articulates that it may be both robust and archaic, and that Hong Kong's political and economic ties to China have likely impacted the shape of its short selling system.

The practice of short selling was banned until the 1990s. A pilot scheme was then introduced in 1994 allowing covered short selling for a limited number of stocks and subject to a tick test. The system was revised in 1996; the tick rule was removed and the number of securities eligible for short selling increased (essentially the practice was permitted for large and liquid stocks (or 'designated securities'). In line with the SEC's approach after the 2008 crisis, Hong Kong re-introduced a tick test after the shorting of the Hong Kong Dollar during the Asian financial crisis in 1997 (although exemptions exist for market-making activities. There is also a permanent ban on naked short selling. ${ }^{42}$

For designated stocks that can be sold short, the 'eligible list' is revised quarterly and the Hong Kong Exchange (HKEx) publishes a list of criteria on its website. ${ }^{43}$ Hong Kong also has tight settlement rules; if a broker fails to deliver on $\mathrm{T}+2$ then a compulsory buy-in will be executed. ${ }^{44}$ There are disclosure requirements to the regulator concerning net short positions. These apply, broadly, where the net short position is equal to $0.02 \%$ of the market

${ }^{36}$ ESMA, List of Administrative Measures and Sanctions Applicable in Member States to Infringements of the Short Selling Regulation (June 2017).

${ }^{37}$ Regulation (EU) No 596/2014 of 16 April 2014 on Market Abuse Regulation [2014] OJ L 173/1; Directive 2014/57/EU Of16 April 2014 on Criminal Sanctions for Market Abuse OJ L173/179.

${ }^{38}$ Eilís Ferran, 'After the Crisis: The Regulation of Hedge Funds and Private Equity in the EU' (2011) 12 EBOR 379.

${ }^{39}$ Karmel (n 18).

${ }^{40}$ CEO Martin Wheatley, SFC on Short Selling (Setempber 2008).

${ }^{41}$ David Webb, Proposed Law Sells HK Short (2010) (a former Hong Kong Stock Exchange director).

${ }^{42}$ Eric Chang, Joseph Cheng and Yinghui Yu, 'Short-Sales Constraints and Price Discovery: Evidence from the Hong Kong Market' (2007) 62 J Fin 2097, 2101.

${ }^{43}$ HKEx, Rules of the Exchange: Short Selling Regulations (Schedule 11) .

44 'Regulation of Short Selling Activities' The Government of Hong Kong Press Release (28 June 2017) <http://www.info.gov.hk/gia/general/201706/28/P2017062800425.htm> accessed 12 September 2018. 
capitalisation of the issuer, or HK\$30 million, whichever is lower. ${ }^{45}$ The SFC also publishes aggregated short positions for each stock on an anonymous basis, typically a few days after receiving the short selling report. ${ }^{46}$

The cognate literature suggests that political motivations can influence the HKEx's decision as to which stocks can be sold short via the designated list. Choi and Huszar suggest it is possible that there are regulatory collaborations between China and Hong Kong and that in addition to the stock exchange's officially declared criteria, there are other unobservables influencing the regulators' decisions. ${ }^{47}$ In particular, although the HKEx is a listed company, its largest shareholder is the Hong Kong Government (with a six per cent holding as of June 2018), who has considerable control over it. ${ }^{48}$ There are arguments to the effect that the HKEX does not allow short selling in relation to large firms with major influences in China (including large industrial firms such as Swire Pacific Ltd). In particular, where the stocks are also listed on Mainland Chinese exchanges, shorting on the HKEx may be strategically banned to prevent persistent mispricing across the markets. ${ }^{49}$

While the HKEx manages the shortable list, the operationally independent securities regulator, the Securities and Futures Commission (the 'SFC'), is responsible for regulating the securities and futures market. It regulator has taken numerous actions with respect to market misconduct, and the short sale provisions can be enforced extra-territorially. ${ }^{50}$ Accordingly to Donald there have been 94 enforcement notices in relation to short selling on a rolling basis between 1997-2013. ${ }^{51}$ The SFC's 2017-18 report stated there was one conviction leading to a fine for illegal short selling activities, plus 78 investigations into market manipulation. ${ }^{52}$ In 2018, enforcement actions have included convicting and fining an account executive for illegal short selling. ${ }^{53}$

Taken together, the Hong Kong regime is certainly robust, in the sense that it is extremely strict, but it is also archaic in that not all shares can be sold short. ${ }^{54}$ Its on-going relationship with China and the related political drivers may influence how its regulators make decisions about its short selling regime. More broadly Hong Kong's system can been seen to have some

\footnotetext{
${ }^{45}$ Note that a sole HK $\$ 30$ million threshold applies for units in collective investment schemes.

${ }^{46}$ SFC, Short Position Reporting - FAQs (November 2017).

${ }^{47}$ See Darwin Choi and Zsuzsa R. Huszár, 'Evaluating Regulators: The Efficacy of Discretionary Short Sale Rules' Working Paper, January $2016<$ file://Users/elizabeth/Downloads/SSRN-id2627908.pdf> accessed 11 September 2018.

${ }^{48}$ The Government appoints six of the Board's 13 members; it approves the Chairman and gives a prior recommendation on the Chief Executive. Hong Kong law also provides that no entity shall hold more than five per cent of the HKEx without approval from the SFC after consultation with the government's Financial Secretary, Securities and Futures Ordinance, division 4 - Exchange Controllers, section 61; 'Government Increases Shareholding in Hong Kong Exchanges and Clearing Limited to 6 Per Cent' Hong Kong Government Press Release (6 June 2018) $<$ http://www.info.gov.hk/gia/general/201806/06/P2018060600751.htm> accessed 11 September 2018.

${ }^{49}$ Darwin Choi and Zsuzsa R. Huszár (n 47).

${ }^{50}$ Dorsey \& Whitney LLP, The SFC's Extra-Territorial Reach - Part 3 (the Court of Appeal in Hong Kong Dismissed an Appeal of the U.S. Short-Seller Who Was Found Culpable of Market Misconduct) (February 2017)

${ }^{51}$ David C. Donald (n 4) chapter 5, section 3.

${ }^{52}$ Securities and Futures Commission, Annual Report 2017-18 166.

${ }^{53}$ Securities and Futures Commission, Account Executive Convicted and Fined for Illegal Short Selling (July 2018).

${ }^{54}$ David Webb (n 41).
} 
functional analogies with the US and EU. The political pressures placed on the HKEx to protect large Chinese companies can be viewed as functionally similar to those on the SEC and EU regulators to protect certain shares during the global crisis, and for the EU to introduce sovereign debt restrictions following the euro-zone crisis. Despite these analogies, however, as section 4 discusses, there remain notable divergences between the jurisdictions.

\section{$4 \quad$ International Principles vs. Divergent Regulation}

IOSCO generally responded to the global financial crisis by recommending additional regulation. But this was not so with respect to its views on short selling regulation. Rather, as witnessed in section 3, IOSCO's response was to limit political pressure for permanent short selling bans, or the use of uptick rules. ${ }^{55}$ Notwithstanding IOSCO's measured response, the US, the EU, and Hong Kong have chosen to plough their own furrow with respect to how they regulate the practice. Hong Kong has a permanent ban on short selling shares not on the eligibility list; Hong Kong and the US have a form of uptick rule in place, and the US exemptions do not extend to its tick rule. The EU's legislation is most aligned with the general thrust of the IOSCO principles, but it stands alone in its specific constraints on short selling sovereign debt. At the enforcement end, all the regimes can have extra-territorial reach and the Hong Kong and US regulators appear willing to police short selling abuses. In the $\mathrm{EU}$, the overall effect of its legislation is lessened by enforcement being a Member Statespecific matter. If it chooses to regulate short selling as a regional matter then developing pan-EU enforcement is also necessary rather than utilising the pre-crisis multiple enforcement model. $^{56}$

Whether at the level of autonomous territory, nation state, or regional grouping, the varying responses generate problems when an activity, such as short selling is of a global nature. Of itself this raises a niche issue for the UK in light of Brexit. Although investment firms will remain subject to the EU's SSR to the extent this applies extra-territorially, the SSR is unpopular with industry. Moreover, the UK regulator has also raised concerns that the SSR could have unintended consequences and negative effects on liquidity. ${ }^{57}$ Accordingly, this could be a law the UK allows to lapse over the longer-term. This would certainly be rational from an economic perspective; as this paper has argued, short selling enhances market efficiency. Nevertheless, if the decision is taken to introduce a bespoke UK short sale regime (perhaps with flavours of its pre-SSR stance as witnessed in section 3) then this could risk further complicating matters for market participants. This paper has suggested that the presence of numerous regimes is distortive and costly for firms who have to cope with the differing rules in operation. The influence of unilateral responses also leads to externalities in other markets. Traders learn how to game the system through inventing synthetic equivalents or shifting trades to unregulated markets.

In this regard, and although the IOSCO principles are not sufficiently detailed as a template for international harmonisation, they do offer a level of clarity. Accordingly their full endorsement by IOSCO jurisdictions would help to simplify the overall level of compliance for participants. At the same time, the paper acknowledges that international legislation is an unfeasible aim. In particular IOSCO has neither the clout, nor the proper enforcement mechanisms (aside from peer pressure) to impose its stance on jurisdictions that choose to

\footnotetext{
${ }^{55}$ Karmel (n 18).

${ }^{56}$ At the same time, as observed above, this issue is now tempered via the alternative avenue of the EU's market abuse regime that contains pan-EU enforcement measures.

${ }^{57}$ See ACA Compliance, Looking across the Brexit Void: What Will Happen to Your Business If the UK Votes to Leave the EU? (2016); The Financial Conduct Authority's Response to the European Commission's Call for Evidence on the EU Regulatory Framework for Financial Services (2016).
} 
tackle regulation in a different fashion. The end result, however, is a failure of international financial regulation. ${ }^{58}$

\section{Conclusion}

Financial economists have extensively researched short selling and the imposition of short selling restrictions. This research is remarkable for its largely consistent conclusions that short selling enhances market efficiency. These benefits are intricate and can be long-term in nature rather than the short-term political point scoring that emerges in the aftermath of a crisis when it is en vogue to be against speculators. The paper has demonstrated that the politicisation of this topic produces diverging regulatory responses and results in complex sets of rules that can hinder valuable and legitimate short selling activity. Short selling is undoubtedly a sensitive topic, but if it is to be regulated, it merits implementing and enforcing global rules. This is unrealistic, but so are the inconsistent, go-it-alone approaches adopted by the IOSCO's members.

\footnotetext{
${ }^{58}$ Karmel (n 18).
} 